\title{
Ungrammaticalities in the Standard Igbo
}

\author{
Thecla Udemmadu \\ DOI: http://dx.doi.org/10.4314/ujah.v14i1.6
}

\section{Abstract}

Ungrammaticality is a phenomenon that is not associated with the use of the mother tongue. This is because the mother tongue is naturally acquired in the environment of its domain. This paper sets out to provide evidence of the possibility of ungrammaticality in the mother tongue. But this exists as result of interference from dialectal varieties of the Igbo language. The research work identifies some of the ungrammaticalities observed in the standard Igbo which represent dialectal features. The data for the research were collected through observation of native speakers' speech event, and the analysis was done using the approved principles for the standard Igbo. The errors identified include: personifying inanimate things, impersonifying man, improper application of plural markers, indirect repetitions otherwise known as tautology, improper use of the first person singular pronoun and wrong use of some diction, among others. The researcher recommends that native speakers should adhere to the principles of the standard form of the language because any native speaker is a potential informant to linguists and language learners. This paper therefore contributes immensely to the goal of better teaching and learning of the standard Igbo.

\section{Introduction}

Ungrammaticality is a notion used by linguists to describe utterances that do not conform to the rules of a particular language. Fromkin, et al (2003:597) say that, ungrammatical 
are structures that fail to conform to the rules of grammar, conversely, when we say that a sentence is grammatical, we mean that it conforms to the rules of the grammar. According to Bussmann (1996:196), "grammaticality is a term coined by Chomsky (1965) to indicate the wellformedness of expressions of natural languages". A grammar of a language is an account of the language's possible sentence structures, organised according to certain general principles. The American linguist Noam Chomsky writes that a grammar is a 'device of some sort for providing the sentences of the language under analysis', (Crystal, 1987). Ungrammaticality is not usually associated with the Mother Tongue (MT) because MT is acquired in the natural environment, and it is usually the first language of an individual. Many of the works on error analysis therefore focus on the users of a second language not users of MT. But here, we present some data of grammatical errors made by native speakers of the Igbo language. The speakers who have been observed are mainly speakers (between the ages of ten and fifty years) of Igbo around Agulu speech community. Agulu is largely a homogenous Igbo speaking community.

It is glaring that every individual has an innate potential to master the spoken pattern of his mother-tongue, but there are certain non-linguistic factors that can propel him not to be efficient as suppose, such as trend, slangs, and influence of peer among others. For this Crystal (1995:184) says, "An error may not always be noticed but if it is, there is a real risk of peer group derision. As a matter of fact, those non-linguistic factors are not supposed to debar one from mastering his mother-tongue which is the only language he acquires without making conscious efforts." But thorough observation has revealed that most native speakers of the Igbo language 
(especially people below middle age) indulge in grammatical errors.

\section{Some Evidences of Linguistic Errors among Igbo Speakers}

The commonest Igbo grammatical errors manifest mainly in the use of singular nouns/pronouns and plural nouns/pronouns. Ogbalụ (1957:36) confirms this by remarking that, "Prolific source of error is in the use of plural noun for singular and vice versa' Example- 'Abụ m ụmụaka', instead of 'Abụ m nwata', 'Anyị bụ nwata' instead of 'Anyị bụ ụmụaka'." Oluikpe (1985:15) says, "A pronoun must agree in number, gender and case with its antecedent, thus, pronoun replacing a noun must have the same number as the noun it replaces." Hence, the ungrammaticalities observed among Igbo speaker can be grouped into:

i) concord disagreement

ii) tautology

iii) impersonifying human being

iv) personifying inanimate things

v) wrong selection of verbs

vi) distortion of meaning

\section{Concord Disagreement}

This is where most speakers of the language are found wanting. Look at these expressions:

1. * 'Ngọzi na Ebere bụ nwanne' (Ngozi and Ebere are sister). ' Ngọzi na Ebere' are compound subject (or plural subject), but the pronoun 'nwanne' that replaced them is singular. So, the construction is vividly wrong because it violates the rule of concord or agreement It is proper to say, 'Ngozi na Ebere bu umunne' 
2. * 'Ifeoma na-eme ka umuazi'. (Ifeoma is behaving like children). 'Umụazị' which is a plural pronoun cannot agree with a singular noun 'Ifeoma'. This violates the rule of concord agreement. It is better to say, 'Ifeoma na-eme ka nwata.'

3. * 'Oọ umuazi na-enye Ada nsogbu'. This construction is ambiguous in the sense that one cannot pin down a particular meaning to it. If the speaker means that 'children are disturbing Ada' (at the surface meaning) it is correct. Take for instance, if one is asked, 'Gịnị na-enye Ada nsogbu n'abalị?" (What disturbs Ada in the night?). The answer can briefly be, 'Oọ ụmuazị na-enye Ada nsogbu'. But on the other hand, if the speaker intended to mean that childish behaviour is disturbing Ada' (which is figurative) the construction becomes wrong because 'ụmuazị' is supposed to go with a plural noun. The better way to put it is, 'Oo nwata na-enye Ada nsogbu.'

4. $\quad$ * 'Otu n'ime ndị nkuzi ha na Emeka bi bụ Maazị Okoye'. (One of the teachers whom Obi lives with is Mr. Okoye). This sentence is ungrammatical because the pronoun 'ha' is not supposed to go with 'otu n'ime' (one of $\cdots$ ) The construction has to have a singular pronoun to become, 'Otu n'ime ndi nkuzi ya na Emeka bi bụ Maazi Okoye'.

5. $\quad$ * 'O dịghị onye ma ụzọ ibe ha si mgbe agha dara'. (Nobody knew the whereabout of one another when the war broke out). The appropriate thing to say is, ' $O$ dighi onye $m a$ uzo ibe ya si mgbe agha dara'.

6. $\quad$ *Ka $o$ pụọ. ( Let me alight or let me get down)

This is where virtually everybody is a culprit especially passengers (people who travel with public transport). This 
blunder has been adopted as a tradition, and it seems to have come to stay because even when someone tends to say the correct thing, people look at him as a stranger. A passenger who wants to alight a vehicle shouts to the conductor, 'Ka o pụọ' when referring to himself. The conductor in effect tells the driver 'Ka o pụo'. The utterance itself is very correct grammatically and syntactically. But when semantically analysed, it is wrong because the context in which it is used is absolutely wrong. We now talk about the contextual meaning which is the meaning an expression connotes depending on the situation or context under which it is uttered, thus, the context influences the meaning. According to The New Encyclopedia Britannica (1973:221), "Nearly all everyday words have more than one meaning, and it is only the context or whole situation that shows the hearer how a particular word is to be taken." The context under which an utterance is made is very important- Crystal (1987:102) notes that, "In modern linguistics, meaning is studied by making detailed analysis of the way words and sentences are used in specific contexts." In the structure, ' $\mathrm{Ka}$ o pụo', the pronoun ' $\mathrm{O}$ ' is the $3^{\text {rd }}$ person singular pronoun. It denotes that some other person is going down not probably the person talking. This type of blunder has to do with the concord disagreement because the pronoun and its referent do not agree. Among non-Igbo indigenes residing in Igbo land, it is pardonable to tolerate the flaw because, they always hear conductors say, 'Ka o pụọ', so, they probably mimic the conductors when they want to alight. But, there is no excuse for an Igbo native speaker- The appropriate thing for a passenger to say when he wants to alight is, 'Ka $\mathrm{m}$ puo'. For the plural it is, 'Ka anyi puo'.

7. $\quad$ * 'Kedu ka $i$ mere?' ( How are you?), responds, ' $O$ dị $\mathrm{mma}$ ' (It/he/she is fine)

There is a violation of concord rule here because the pronoun in the question does not correspond with that in the response- 
The question was referring to the $2^{\text {nd }}$ person singular pronoun ' $\mathrm{i}$ ', but the response was referring to the $3^{\text {rd }}$ person singular pronoun 'o'. The response is totally wrong contextually. The correct response is 'Adi $m$ mma' for the question, 'Kedu ka i mere'? But, if the question is, 'Kedu ka o di?' (How is it?), the response should be, 'O di mma' (It/he/she is fine)

8. * 'Unu o gbara ọsọ?' (Did you people run?) This interrogative statement does not need the $3^{\text {rd }}$ person singular pronoun 'ọ'. It is better to say, 'Unu gbara oso?' The 'ọ' can be accepted in interrogative statement like, 'Ebere o gbara ọso?'

9. $\quad$ * 'Obodo obụla nwere ihe ha na-aso' (Every town has norms) - 'Obodo obụla' is an entity so, should go with a singular pronoun. Hence, 'Obodo obula nwere ihe $o$ na-aso' or 'Obodo di iche iche nwere ihe ha na-aso'

\section{Improper Use of 'ndị'}

The use of 'ndi' when code-switching is also highly misused by Igbo speakers · For example,

10. * 'Ndị bishọpụsị na ndị kanselọsị nwere nzukọ ụnyaahụ'· (Bishops and Councillors had meeting yesterday)

Looking at the above construction at a glance, one may not decipher the error But critical analysis reveals that it is wrong because 'ndi' is already a plural marker and does not require another plural marker. There is code-switching in the sentence, but the word 'ndị' has already pluralized 'Bishọpụ' and 'Kanselọ', so the plural marker 's' attached to Bishop and Councillor is not call for. This is what Coulmas (2000:25) portrays when he says, "Convergence is another contact phenomenon on the bilingual continuum, even though under 
convergence all morphemes in utterance come from a single language." So, the morphemes such as the plural marker 's' is supposed to come from one language. Since Igbo is the metalanguage, the plural indicator has to come from it- It is therefore, better to say, 'Ndi Bishopu na ndi Kanselo nwere nzuko unyaahu'

11. * 'Ndị Semineriansị abịala' (The Seminarians have come) instead it should be 'Ndi Seminari abiala'

12. * * 'The oggugụ anyị nke taa si n'akwụkwọ ndị Romansị' (Our today's reading is from the book of Romans) is better to have, 'Ihe ogugu anyii nke taa si n'akwukwo ndi Rom'

13. * 'Ndị Naijjiriansị ma agba bọọlụ' (Nigerians know how to play football) better put as, 'Ndi Naijiria ma agba boolu.

It is necessary to point out here that 'ndi' means 'people of' in the Igbo language, 'people of Nigeria or Nigerian' is 'ndi Naijirịa' and so on. So, the addition of 'ndị' to Nigerians makes nonsense of the entire construction.

\section{Tautology}

Some speakers are in the habit of stuffing an expression with different lexical items that are connotatively or semantically the same thereby indulging in tautology. Below are some instances:

14. * 'Anyị na-aga ụka kwa ụbọchị Mọnde obula'· (We go to church every Monday) 'Kwa ụbọchị Mọnde' and 'Mọnde ubọchi' are typical tautology when piled up in a sentenceThey perform the same semantic function in a construction- It is preferable to either say, "Anyi na-aga uka kwa ubochi Monde' or 'Anyi na-aga uka ubochi Monde obula' 
15. * 'Mmadụ ncha niile ka a chọrọ taa'(Everybody is wanted today). 'Ncha' and 'niile' have the same semantic connotation; therefore, the presence of one renders the other redundant- Instead, either of them can perform the grammatical function of 'quantifier'. Thus, 'Mmadu niile ka a choro taa', or 'Mmadu ncha ka a choro taa'.

16. * 'Onye niile nọ ebe a ga-eso'(Everybody here will be included). It is grammatical to say either, 'Onye obula no ebe a ga-eso', or 'Ndi niile no ebe a ga-eso.'

17. * 'Ọa mmadụ niile zukọro'(Group of people gathered). It is better to say, 'Oha mmadu zukoro', or 'Mmadu niile zukoro'

18. * 'Chineke achọghị onwụ onye ome njo'’ (God does not want the death of a sinner·) 'Ome njọ' and 'onye njọ' are semantically the same, so adding two of them in a construction is a mere duplication of meaning. Thus, 'Chineke achoghi onwu onye njo' or 'Chineke achoghi onwu ome njo'

19. * 'Otutu okwu ufọdu adịhị mma·'(Too many words are not necessary/ Some words are not necessary) A competent speaker chooses any of the quantifiers (either 'ọtụtụ' or 'ụfọdụ'), to say, 'Okwu ufodu adighi mma, or 'Otutu okwu adighi mma' depending on what the speaker means

20. * 'The na-eme oge ugbua ajoka''( Things are bad these days). 'Oge a' and 'ugbua' are semantically the same. It is better to say, 'Ihe na-eme ugbua ajoka' or 'Ihe na-eme oge a ajoka'. 
21. * 'O na-eduzi m 'ezi' ượ' (He leads me to the right path). 'zi' in 'eduzi' shows positivity. ''Ezi' denotes good. Therefore, it is a tautology to add 'eduzi' and 'ezi' in a construction. It is better to delete any of them to get, ' $\mathrm{O} n a$ eduzi m uzo' or better still, 'O na-edu m ezi uzo'

22. * * O tere nsị akpana okuko n'ukwu' (He rubbed fowl's excreta on his leg).

In Igbo lexicon, the fowl excreta is known as 'akpana'. It is therefore, a mere duplication of meaning and waste of words to add 'nsi akpana'. The question is, does 'akpana' modify 'nsị'? 'Akpana' is 'nsị ọkụkọ'. So, 'akpana' has no excreta. It is 'okukkọ' that modifies 'nsi'. Hence, it is semantically better to say, 'O tere nsi okuku n'ukwu' or better still, 'O tere akpana n'ukwu'

23. * 'Ngọzi mụru ejima abuo' (Ngozi was delivered of a set of twins)

Here, the lexeme 'ejima' means twins, so adding 'abụọ' (two) to 'ejima' (twins) translates to four mathematically. The appropriate thing to say is just, 'Ngozi muru ejima.'

24. * 'Onye chịburu ala anyị n'oge gara aga bụ...' (Our former Head of State is $\cdots$ )

Here, it is better to say, 'Onye chiburu ala anyi bu...' or 'Onye chiri ala anyi n'oge gara aga bu…'

25. * * 'Wetere m ite ahụ mmanụ dị n'ime $y a$ ' (Bring to me that pot that contains oil inside). This structure looks correct but critical review reveals that it is unnecessary to insert the pronoun 'ya'. Without 'ya' the sentence is still accurate and passes all the message Oluikpe (1985:85) points out that, "It is not enough to know how to avoid writing monotonous sentences, you need also to be aware of the most common 
grammatical errors that mar your efforts in writing effectively." It is better to say- "Wetere $m$ ite ahu mmanu di n'ime'. Since the two ideas are embedded into one sentence, the pronoun 'ya' is redundant and therefore should be deleted. This is so because when one clause is subordinate to the other during relativisation, the second NP (or the equi NP) is deleted-In this construction, we have two sentences; 'Wetere $m$ ite ahụ', and 'Mmanụ dị n'ime ite ahụ'· The object(NP) of the matrix and embedded sentences is one and the same entity, which is 'ite ahụ'. The equi NP should be deleted- Therefore, 'ya' has no trace in the construction.

The same is applied to:

26. * 'Chineke onye ike niile dị n'aka ya' (God who all powers belong to) is supposed to be 'Chineke onye ike niile dị n'aka.

\section{Impersonifying Human Being}

Most speakers make mistake of removing life from human being by using inanimate words- For example,

27. * 'Nneka bu ihe nyere m akwukwọ'. (Nneka is what gave me the book)

Animate things like man are not supposed to take inanimate pronouns- Human beings go with personified pronouns and vice versa To support this, Oluikpe (1985:85) notes, "Pronoun replacing a noun must be a neuter if the noun is neuter" So, there is no how, it is correct to say, "Nneka bu ihe...' 'ihe' is for inanimate things against 'Nneka' who is a human being. To make the construction better, it will be, 'Nneka bu onye nyere m akwukwo' 'The same blunder is committed even in the plural animate things like- 
28. * 'Toochukwu na nna ya bụ ihe riri ji' · (Toochukwu and his father is what ate the yam). Toochukwu and the father are supposed to carry plural pronoun- In the recent times, replacing the indefinite pronouns 'ndi' and 'onye' with the inanimate pronoun 'ihe' is spreading like a wild fire that it is always on the lips of every Tom, Dick and Harry. For the plural, the correct thing is 'Toochukwu na nna ya bu ndi riri ji'. It is noticed that the blunder is mostly committed when 'bu' is inserted in the expression. To avert the mistake, one can delete 'bụ' and simply say- 'Toochukwu na nna ya riri ji'. Better still, 'Toochukwu na nna ya bu ha riri ji'.

\section{Personifying Inanimate Things}

When one uses words meant for human beings for non- human being is shows communicative incompetence- For example, 29. *Akpa m no n'ime ụgbọala. (My bag is in the vehicle).

' $N o$ ' is a stative verb because as Ikegwu (1991:32) rightly says, "Stative verbs are verbs that express the state of being or condition which are more or less permanent like, 'nọ', 'dị'". The above expression is very wrong because life is assigned to a lifeless thing 'akpa'. The object 'akpa' is personified by associating it with 'nọ'. This expression is common with the Oweroid dialect of Igbo language (Ikekonwụ,1987) The construction is wrong when compared with the standard Igbo. One should not forget that a stative verb like 'nọ' goes with animate thing, while 'dị' goes with lifeless things Any competent speaker of the standard form of the Igbo language should know that 'akpa' has no legs or buttocks to stay in the 'ugbọala'. It can only be kept there. The correct expression is 'Akpa m di n'ime ugboala'

30. * 'Ewu di n'ọba na-eri ji'. (The goat inside the barn is eating yam)

What is applicable to No. 29 also manifests in this construction. 'Ewu' as a living thing goes with the stative verb 
'nọ'. Another problem with that expression is that in restrictional selection of Igbo verbs, the animal 'ewu' goes with 'na-ata' instead of 'na-eri'. So, it is better to say, 'Ewu no $\underline{\text { n'oba na-ata ji' }}$

\section{Wrong Selection of Verbs}

Sometimes, Igbo speakers apply wrong diction or register especially in the verb of cooking, planting and buying. An appropriate register depicts a competent speaker.

Look at these:

31. * 'Ka m sie ofe' is supposed to be 'Ka m tee ofe'

32. * 'Ọ na-aku ji' should be 'O na-eso ji'.

33. * 'Ada na-esi stuu' is better put as 'Ada na-eghe stuu'

34. * 'O na-aku ose n'ubi' is supposed to be 'O

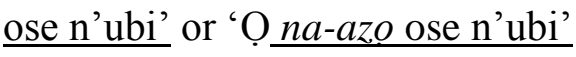

35. * 'Ndị Igbo na-aruputa ji nke ukwuu', is corrected as 'Ndi Igbo na-akoputa ji nke ukwuu'

36. * ' Nna ya zutara ehi' is supposed to be 'Nna ya kputara ehi'

37. * Anyị zutara ala n'Ọa' is better to be 'Anyi gbatara ala n'Oka'

This has to do with semantic selection of Igbo verbs. (Anoka, 1983)

\section{Distortion of Meaning}

38. * 'Ọịa gbochiri ya agaghị ụka'(Sickness prevented him from going to church) 
Here, two negative indicators cannot go together to produce a negative sentence. Even in mathematics, it is proved that negative plus negative equals to positive $(-+-=+)$. One negative cancels the other to arrive at a positive idea, otherwise one negative marker is enough. In the above construction, 'gbochiri' as a negative connotative word cancels the 'ghi' in 'agaghi!' which is also a negative word- Therefore, it is better to prefix ' $i$ ' to the verb root 'ga' to get 'iga' which is an infinitive so that the construction would be better put as, ' Oria gbochiri ya iga uka', or 'Oria mere na o gaghi uka'.

39. * 'O ga-eme ya n'iche iche.'(He will do it differently)

Ogbalu (1957:41) remarks, "Adverbs of manner are generally expressed by means of compound verb roots, adjectives, nouns, adverbial phrases and adverb sentences e.g. O bịara ngwa ngwa." The word serving as an adverb of manner must be duplicated completely not partially. Therefore, the correct expression for the above is ' $\mathrm{O}$ ga-eme ya iche iche.'

40. *'Akụkọ ahụ ruru ala Naịjirịa gbara gburu gburu’(The news spread all over Nigeria). The construction is faulty because Nigeria is not 'gburu gburu'. It is 'gburugburu Nai $\square$ jiri $\square$ a' This blunder is commonly found among Igbo newscasters A Akuko ahu ruru gburugburu Naijiria is better.

41 * *Anyị bụ ndị Anambara Steeti (We are from Anambra State). The convention adopted for writing the Igbo language says, it should be 'Anyi bu ndi Steeti Anambara,' (SPILC, 1985).

\section{Recommendations}

As a way off the hook, all hands should be on deck - Teachers and enlightened people have much to do, not only in the classrooms, but also in public places whether formal or informal For this, Folarin (1975:59) avers, "Teachers have to 
be able to serve at least as a possible model if they would handle these problems". More often than not, workshops should be organised for teachers and students by experts in the Igbo language, so as to acquaint some ignorant teachers about the present position of the language. The teachers in turn can impact those knowledge to their students at all levels. More so, strict rules and guidelines should be stipulated for Igbo as in other languages like English. Ọgbalụ (1957:36) suggests, “It might be good for strict rules to be observed as in English, even though the expressions seem very normal to average Igbo speakers." Average speakers of the Igbo language are myopic in identifying those grammatical blunders, so a laid down grammatical rules should be formulated to guide all.

The issue demands urgent attention because the rate at which grammatical inadequacies in Igbo language is spreading with reckless abandon might inject virus that can infest the language and can lead to retrogression of the language- This does not augur well for a sustainable language development.

\section{Conclusion}

The above enumerated and diversified instances disclosed that it is not an overstatement to say that majority of Igbo native speakers who have Igbo as their first language commit various kinds of grammatical blunders. Since ungrammaticality is not associated with mother-tongue, it is possible that the errors may be associated with influence of social factors, such as, influence from L2 (English) because most Igbo speakers attach more importance to the English language. Other factors are peer influence, trend, slangs, dialect variation, inattentiveness to the meaning of uttered words. The consequences of this are grave for theories of ungrammaticality and grammaticality. The researcher therefore, advocates that more efforts should be 
made to conform to the rules of the Igbo language because any Igbo speaker is a potential informant for non-Igbo linguists.

This research work will be concluded with the words of Crystal (1987:91),

Nonetheless, our language can let us down, we encounter ambiguity, impression and unintelligible speech or writing. To deal with these problems, we need to put grammar under the microscope and work out what went wrong. This is especially critical when children are learning to emulate the standards used by educated adult members of their community.

Udemmadu Thecla lectures in the Department of Igbo, African \& Asian Studies, Nnamdi Azikiwe University, Awka.

\section{References}

Anoka, G.M.K. (1983). 'Selectional Restriction: Verbs Meaning 'to buy' in Nwachukwu, P.A. (Ed.), Reading on the Igbo Verb. Ibadan: Africana-Feb. Publishers, pp. 171-206.

Boadi, I (1977). Grammatical Structure and its Teaching. Lagos: A.U.P.

Bussman, H. (1996). Routledge Dictionary of Language and Linguistics. London: Routledge.

Coulman, F·(2000). The Handbook of Sociolinguistics $\cdot$ U.S.A: Blackwell Publishers.

Crystal, D- (1987). The Cambridge Encyclopedia of the English Language. London: Cambridge University Press.

Folarin, A·(1975). 'Problems of Students' English Journal of Nigerian English Association. Ibadan: University of Ibadan Press. 
Fromkin, V·, Rodman, R·, Hyams, N· (2003). An Introduction to Language ( $7^{\text {th }}$ ed.) Boston: Thomson Wadsworth.

Ikegwu, B· (1991). In Olu: A Journal of Nsukka Linguistics Association Nsukka: University Press.

Ikekonwu, C. I. (1987). Igbo Dialect Cluster: A Classification. (Departmental Seminar Series .Department of Linguistics / Nigerian Languages, University of Nigeria, Nsukka.

Ogbalu,F.C.(1957). School Certificate Igbo. Onitsha: University Publishing Company.

Ogbalu, F.C. (1974). Standard Igbo-Path to its Development. Onitsha: University Publishing Company.

Oluikpe, B·(1985)'The Use of English for Higher Education. Onitsha: Africana-Fep Publishers.

Oruchalu, S·(1979) · The Fundamentals of Igbo Spelling· Ihiala: Deo Gratias Press.

Palmer, F- (1981) Semantics (2nd ed). Britain: Cambridge University Press.

SPILC (1985), Ọkaasụu Igbo- Igbo Meta Language. Nigeria: Varsity Industrial Press

The New Encyclopedia Britannica (1973). Vol.16. London: William Benton Publisher. 